\title{
BRAZILIAN MUSIC BETWEEN NATIONAL AND \\ REGIONAL
}

ANDREJ TOMAZIN

After Brazil became independent in 1822, intellectuals and politicians were confronted with the question of how to create a common identity that would connect the vast territory and the communities living there into a single whole. Along with the national identity, regional ones were formed as well, marked by the desire to preserve their own cultural expression within the larger state. Under the influence of the mass media, folk musical expressions contributed to the emergence of popular music, which was also influenced by the elites, who acted as gatekeepers and arbiters.

Keywords: Brazil, music, identities, cultural nationalism, Nordeste, Northeast Brazil, samba
Po osamosvojitvi Brazilije leta 1822 so se intelektualci in politiki spoprijeli z vprašanjem, kako ustvariti skupno identiteto, ki bi v celoto povezala razsežno ozemlje in tam živeče skupnosti. V procesu oblikovanja nacionalne identitete so nastajale tudi regionalne, ki jih je zaznamovala želja po ohranjanju lastnega kulturnega izraza znotraj večje države. Pod vplivom množičnih medijev in elit, ki so delovale kot vratarji in hkrati razsodniki, so ljudski glasbeni izrazi prispevali k nastanku "brazilske" popularne glasbe. Ključne besede: Brazilija, glasba, identitete, kulturni nacionalizem, Nordeste, severovzhodna Brazilija, samba

\section{INTRODUCTION}

National and local identities emerge as a mosaic of individuals' influences. Although it is common to perceive folk culture as spontaneously created and sometimes even as present since time immemorial, it is important to bear in mind that everything created by man arises from personal motivations and interests and is integrated into the national culture through the influence of social elites ${ }^{1}$. This article uses theoretical, historical, and ethnographic sources to present a historical overview of the development of popular music in Brazil, thereby showing the contexts that led to the development of the musical expression of an area. The first part uses individual cases to outline the sequence of events that led to the development of Brazilian cultural nationalism and the placement of samba as the central Brazilian musical genre. The second half of the article presents how these same processes worked in developing regional identity, with a particular emphasis on describing the creation of the (imagined) region of Nordeste. The product of a dialogue between creators and decision-makers is what the observers ultimately perceive as national or regional musical expression.

1 Anja Moric writes about a similar situation - how social elites such as researchers, students and teachers influenced the spread of identification with German culture among Gottscheers in the current issue of Traditiones (Moric 2020). 


\section{THE HISTORICAL CONTEXT OF BRAZILIAN CULTURAL NATIONALISM}

As the Brazilian artist Caetano Veloso (2003: 3) ironically points out in his memoirs about the tropicália art movement, the entire American continent recognizes Columbus' "discovery" in 1492 as the beginning of the emergence of its modern countries, whereas Brazil places its beginnings later, in 1500, when the Portuguese expedition missed their route and landed on the Island of the True Cross. After 1549 Salvador in Bahia, in the northeast, became the capital of what would become Brazil, and the Portuguese settlers began cultivating sugar cane and enslaving the natives. Due to difficult working conditions, exploitation, and disease, the number of indigenous people in coastal areas declined rapidly, and the colonizers replaced the lost workforce with enslaved Africans, who by the end of the sixteenth century represented seventy percent of the total population on the plantations. These demographic changes brought with them a new racial nomenclature that is partially still in use today. The offspring of Africans and Europeans were called mulatto or pardo, the children of Europeans and indigenous people were mameluco or caboclo, and a person with indigenous and African roots were called cafuzo. In 1774, the Portuguese united the occupied territory and managed the colony from its new capital, Rio de Janeiro (Williamson 1992: 167-180). Due to the threat of Napoleonic invasion, the ruler John VI moved the entire Portuguese court to Rio in 1808, thereby turning the capital of the colony into the center of the Portuguese empire. When he was forced to return to Portugal in 1821 due to threats to his power, he left his son Pedro I as the regent in Rio; Pedro declared Brazil an independent monarchy a year later (op. cit.: 210-230).

After independence, there was a need for a specific Brazilian identity. The Portuguese crown, which until then had enforced the legitimacy of the ruling class, was gone, and so new stories had to be invented to confer a sense of cohesion on the unconnected multiethnic population: to create what Benedict Anderson calls an "imagined community." Members of such a community are connected by a common idea of belonging, even though they do not know each other and will most likely never meet (Anderson 2006: 5-7). An important factor in creating these community identities is the process Eric Hobsbawm called "inventing traditions"; these promote social cohesion in the community, legitimize it, and cultivate the values and socially variable behaviors of its members (Hobsbawm 2000: 1-14). Influenced by the ideas of Romanticism, in the mid-nineteenth century Brazilian intellectuals sought to find "Brazilian" origins in their supposedly harmonious relationships between the brave Portuguese explorers and the noble indigenous peoples. This was particularly reflected in the literature of José de Alencar, author of the novels $O$ Guarani (1857) and Iracema (1865). In both works, the author labels the children of mixed marriages between the first colonizers and indigenous people as Brazilians, but completely overlooks the enslaved Africans, who were already quite numerous in Brazil at the time the novels were written (Vianna 1999: 39-47; Dunn 2001: 16-21). One of the consequences of the abolition of slavery in 1888 was the increase in the number of free African Brazilians, 
which consequently rendered the romantic ideals of the origins of Brazilian ethnicity in the context of the national mythology somewhat inappropriate. At the same time, a paradigm of positivism was established in intellectual circles, which ideologically merged social Darwinist theories with a biomedical approach and saw certain cultures as more or less "sick" or backward. The main symptom of this "disease" was considered to be a greater amount of melanin in the skin, or the "African characteristics" of the population, which were said to contribute to more primitive cultural development. Positivism, however, was carried out with romantic glorification of the indigenous peoples, who could virtually no longer be found in the more populated parts of Brazil, and with feigning ignorance about the number of Afro-Brazilians, who represented a significant percentage of the population. ${ }^{2}$ European deterministic theories that placed white people at the top of the racial hierarchy and justified poorer economic development with every departure from the "ideal" racial structure of the population were also useless in the Brazilian national cultural context, because racial mixing and the multiethnic reality of the population made it impossible to create a nation according to European ideals (Santos 2002: 74). The theorists therefore found the solution in a specific type of mestization called branqueamento; literally, the "whitening" of the population. Proponents of this "whitening" predicted that a sufficient number of fair-skinned immigrants would satisfactorily "whiten” Brazil's populace in about three or four centuries. There was also considerable political engagement with this concept, and the immigration of desirable Europeans was financially supported, whereas Asians and Africans were even banned from entering the country until 1920. The whitening policy was most enthusiastically implemented in large urban centers in the south of the country and, by 1950, almost ninety percent of people living in Sáo Paulo were white. Over the course of three centuries slave traders had brought 3.5 million Africans to Brazil, but in less than one century following the abolition of slavery the authorities subsidized travel expenses in order to facilitate the immigration of five million light-skinned Europeans, mainly from Italy, Portugal, and Spain (Vianna 1999: 39-50; Borges 1995: 60-72; Reily 2000: 2; Santos 2002: 69-74).

\section{THE DEVELOPMENT OF CULTURAL NATIONALISM}

An important event for the development of cultural nationalism in Brazil was the official start of Brazilian modernism with "Semana de Arte Moderna" (Modern Art Week) in São Paulo in 1922. Modernismo, which aimed to transcend the relationships between "pure" and "impure," or the positivist "healthy" and "sick" (Borges 1995: 69-70), and sought to blend the traditional and the progressive in art, which was to be manifested in the creation

2 For instance, the first census in 1872 showed that only $38.1 \%$ of Brazilians were white (Santos 2002: $61)$. 
of a new art form, poesia Pau-Brasil, ${ }^{3}$ which could be exported from the country. The most prominent ideologues of the movement were Mário de Andrade and Oswald de Andrade (who were unrelated). The musicologist and artist Mário de Andrade, in his "Ensaio sobre a Música Brasileira" (Essay on Brazilian Music) of 1928, thus called on artists to create a national culture that radiated Brazilian authenticity, including through the use of folk motives in composing music. These ideas were put into practice, for instance, by his contemporary, Heitor Villa-Lobos, arguably the most famous twentieth-century Brazilian composer of art music. Another important work by Mário de Andrade from the same year is the novel Macunaima, o herói sem nenhum caráter (Macunaíma: A Hero Without a Character). The author presents the protagonist, Macunaíma, as a sort of satirical metaphor for interracial relationships in Brazilian society, because he is born dark-skinned to an indigenous mother and then "becomes white" after bathing in magical water. Oswald de Andrade was even more radical than Mário, with his most famous works being two manifestos. The first one, from 1924, is Manifesto da Poesia Pau-Brasil (Manifesto of PauBrasil Poetry). In it, he encourages moving away from the colonial heritage and creating a modern Brazilian culture that could be exported just like brazilwood had been four hundred years ago. His Manifesto Antropófago (Cannibal Manifesto; 1928) is more radical. The cannibalism in the manifesto is cultural, though the author sought inspiration from indigenous peoples that ritually consumed the flesh of their adversaries in order to absorb their power. The cannibal native is thus a sort of satirical turn from the romantic noble savage and symbolizes Brazilians that have to cannibalize culture from Outside in order to create something authentically Brazilian. The idea of cultural cannibalism is a new way of thinking about art that does not rely on imitation and cultural protectionism. In art, cultural cannibalization thus cuts across the discourse on linear development, according to which the colonies striving towards sophistication were supposed to merely imitate the European colonizers forever (Vianna 1999: 75-76; Reily 2000: 3-4; Dunn 2001: 12-23; McCann 2004: 131; Murphy 2006: 14-15). A few years after the release of key modernist writings, Gilberto Freyre, a Brazilian anthropologist from Northeast Brazil, also published his most influential study. In the work Casa-grande \& senzala (The Masters and the Slaves, 1933), ${ }^{4}$ which is a mixture of historical ethnography and a story about the origin of the nation, he exposed Brazilian society as having formed through the mixing of the culture and genetics of Europeans, Africans, and South American indigenous peoples. He highlighted mestization as an essential aspect of Brazilian society, and ideologically rejected the paradigm of whitening the populace, but it could be said that to some extent he returned to the ideas of harmonious relations between ethnic groups advocated by intellectuals a century before him. Although his assertions about the pursuit of common goals by the

3 The term denoting the poetry refers to the wood of the Paubrasilia tree, or brazilwood, which the Portuguese exported from the colony (Dunn 2001: 15-17).

4 The title references the dwellings of the masters (casa-grande) and the slaves (senzala). 
Portuguese masters, enslaved Africans, and semi-exterminated indigenous inhabitants are hard to believe today, Freyre nevertheless succeeded in instilling the myth of racial democracy in the collective memory of Brazilians using arguments about the specificity of Portuguese slavery and comparisons with racially segregated countries (Fry 2000: 88-90). Anthony W. Marx (1996: 181-182) points out that it was precisely this concept of racial democracy, which was also supported by the absence of segregation laws in Brazil after the abolition of slavery, that allowed the elites to create an atmosphere of apparent interracial tolerance. Segregation by race was simply covered by social class segregation, which pushed the post-abolition generation of free descendants of Africans to the bottom of society. The folk culture of the Afro-Brazilian population, such as feijoada (a stew made from beans and leftover beef and pork), the folk-popular musical genre samba, and the martial art capoeira, was included in the pantheon of Brazilian national culture by the ruling strata, but only in a decorative sense. This also deprived the dark-skinned population of the possibility of establishing their own cultural identity (Menezes Bastos, in Oliven 1984: 104; Fry 2000: 105). Thus, all these cultural elements were no longer specifically Afro-Brazilian; they became Brazilian - part of the identity of all Brazilians. The idea of racial democracy was so well-established among intellectuals that in the 1950s, at the initiative of the Brazilian anthropologist Arthur Ramos, UNESCO funded a case study of good practice as a lesson to countries with racial segregation (Sheriff 1999: 7; Fry 2000: 90-91). Quite contrary to the idealized concept of harmonious relations, the study findings showed the ubiquity of racial discrimination, and consequently some researchers lost their university positions as punishment (Bollig 2002: 161).

\section{NATIONALIZATION OF SAMBA}

The coup that ousted the ruler Pedro II in 1889 and turned Brazil into a federal republic was followed by a forty-year period of power exchange between the southern federal states of São Paulo, where coffee was grown, and Minas Gerais, where cattle was raised, known within Brazilian historiography as café com leite (coffee with milk). The dispute over political succession led to a new coup that brought Getúlio Vargas, governor of the southernmost federal state Rio Grande do Sul, to power (Williamson 1992: 410-416). This period of the first Vargas government (1930-1945) was also the period of nationalizing the urban samba from the capital Rio de Janeiro.

Historically, the development of musical expression in Brazil was most influenced by the culture of the West African peoples and the folk and popular music brought by the Portuguese colonizers (Vassberg 1976: 39). Although music researchers from the time of colonization highlight different musical practices, including batuque (see Fryer 2000), lundu appears in

5 A term for the musical practices connected with African traditions and instruments. 
the literature as the first equally European and African style of music and dance in Brazil, which, due to its "indecent" dance figures, was banned by the Portuguese ruler already in the first century of colonization. By the nineteenth century, far from the king's eyes, lundu spread among all social classes, especially in situations of socializing between dark-skinned women and the men of European descent. John Charles Chasteen (1996: 31-36) thus cites the example of an English traveler in Brazil between 1802 and 1803 that even referred to lundu as a Brazilian national dance. A slightly more European, yet still eclectic style of music that existed at the same time as lundu is modinha. In the eighteenth century, its finished form was shaped by Domingos Caldas Barbosa, a man of mixed parentage officially considered the "first Brazilian composer." Interestingly, the popularity of modinha went beyond South American borders, and music in this style was composed by Portuguese composers as well (Vassberg 1976: 43-46; Menezes Bastos 1999: 74; Vianna 1999: 18-27). At the end of the nineteenth century, its place was taken by maxixe from Rio de Janeiro. Vassberg describes maxixe as a conglomerate of the aforementioned batuque, the European polka and the Hispano-American habanera (1976: 46). Beginning in the 1870s, instrumental ensembles in Rio de Janeiro developed another important musical style, known as choro. Local aesthetic influences were added to popular European musical forms such as the polka, waltz, mazurka, and quadrille, and thus these dances were played in a more Brazilian manner (Garcia 1997: 58), also due to the selection of instruments. Choro was mostly played on cavaquinho, a small four-string instrument, wooden flute, and guitar, which provided bass lines, and later also bandolim, ${ }^{6}$ clarinet, and ophicleide ${ }^{7}$ (Reily 2000: 6-7; Murphy 2006: 30-31). Most choro performers came from the lower and middle classes and had government jobs that allowed them free time to play music, with the fire department ensemble in Rio de Janeiro having the greatest influence on the development of this musical genre, establishing performance standards that today place choro between popular and art music. An important social aspect of choro was also its racial integration, for which McCann (2004: 163-164) states that on the one hand, it protected the music from police repression, but at the same time for this very reason it was not adopted as a national symbol like samba.

In connection with the emergence of the urban samba in Rio de Janeiro, the almost mythical parties of the early twentieth century at Aunt Ciata's house in Praça Onze in the neighborhood of Cidade Nova are most frequently mentioned. Afro-Brazilian workers settled there after the abolition of slavery and the neighborhood also became known as Little Africa (Moura, in Menezes Bastos 1999: 72). Musicians played lundu, maxixe, and polkas at the parties, as well as batuque and traditional forms of folk samba from Northeast Brazil (McCann 2004: 44-46; Murphy 2006: 7-8). As Vassberg (1976: 46) explains, samba in its original, folk form was the music of Afro-Brazilians. Until about the 1920s, it was rejected and even persecuted by the descendants of Europeans in Brazil, and then radio and record

6 Brazilian type of mandolin.

7 Bass brass instrument. 
labels "civilized" it to the degree that it approached the taste of the middle class through the orchestrations of classically educated arrangers. Thus, for example, in the 1930s, there were several styles of samba, from folk samba in Northeast Brazil to the style of samba suitable for upper social class dance parties in the cities in the south. The title of the first recorded samba belongs to the 1917 Carnival hit "Pelo telefone" (On the Phone), which was created at one of the parties at Aunt Ciata's house. Donga listed himself as the author of the song, which did not sit well with the other musicians present, because the song was apparently the result of collective improvisation. Donga's authorship was further called into question by a 1938 research expedition led by Mário de Andrade, which documented folk music in northern and northeastern Brazil. Namely, a very similar tune was discovered in two recordings of the staging of the folk music-drama interactive play Bumba Meu Boi. Ismael Silva also disputed the special significance of the song "Pelo telephone," claiming that the first recorded samba was his composition "Se Você Jurar" (If You Swear) from 1931. He called Donga's recording a maxixe (Enciclopédia 2017). It was in fact Silva, along with Nilton Bastos and Bide, who was credited with taking a fresh approach to samba, which introduced much more syncopation into its musical expression and stylistically distanced it from maxixe as well as from folk forms of samba. The new sound from the Estácio de Sá neighborhood was much more convenient for the requebrar dance, and it also stopped emphasizing the downbeats, which was typical of the mid-1920s. Three percussion instruments, the surdo ${ }^{8}$, cuica $a^{9}$ and tamborim, ${ }^{10}$ took on a particularly important role in the new way of playing samba, and these innovations soon changed the old way of playing. It is also important to note that the sambistas ${ }^{11}$ from Estácio are also credited with establishing the first permanent Carnival group, named "Deixa Falar" (Let Them Speak), which was then called escola de samba (samba school). It was precisely in the context of the samba school that Bide first introduced the emphasized second beat on the surdo, which is characteristic of popular samba to this day (Shaw 2002: 88; McCann 2004: 47-48; Murphy 2006: 9).

Radio arrived in Rio de Janeiro in 1922. The transmitter was installed on Corcovado, where the famous Christ the Redeemer statue still stands today, while a receiver, along with speakers, was installed on the city square. After an address from the President, an opera adaptation of de Alencar's romantic work $O$ Guarani was played in a pre-modernist spirit. Development of the radio industry began in Brazil in the 1930s. Due to competition from Argentine radio, the populist Vargas government, which lacked its own resources, was forced to allow advertising and thus commercialization of the media space. By the mid-1930s, twelve of the fourteen stations in the capital, Rio de Janeiro, were intended for entertainment programs: mainly live music performances. Vargas wanted to take advantage of the

8 A very deep-sounding bass drum.

9 A friction drum with a membrane and a stick.

10 A small, high-pitched, tuned frame drum.

11 Samba musicians. 
opportunities offered by this new technology and had public radios with speakers installed in smaller cities as well. In this way, residents across the country, with the exception of São Paulo, which had its own stations, were offered music programs based on the tastes of the local urban population (McCann 2004: 8-24). McCann points out that by 1937, the urban samba from Rio had already become the first choice of listeners in most major Brazilian cities (op. cit.: 57-58). In the same year, the Vargas government ordered the samba schools, which multiplied across Rio de Janeiro following the example of Deixa Falar, to emphasize historical, educational, and patriotic themes in their Carnival compositions, the sambaenredo, in accordance with the regime's populism. They established control of the schools by requiring them to register as recreational societies and obtain licenses, and under the influence of the mass media and government sponsorship, the Rio style of Carnival spread throughout the country (Vianna 1999: 90; Murphy 2006: 20).

As an all-Brazilian musical style, the popular samba not only established itself within the country, but in its outward projection transcended the borders of Brazil. As early as 1936, the Brazilian government broadcast a performance of the Mangueira samba school to Nazi Germany on the radio, which is already interesting considering that radio studios were virtually inaccessible to dark-skinned Brazilians, even without tackling the compatibility of this sort of music with Nazi political philosophy (Vianna 1999: 91; McCann 2004: 20-31). Carmen Miranda, however, exported her "Brazilianness" even more concretely. She began her career in Rio de Janeiro, where, among other things, she sang a song by Dorival Caymmi "O que é que a Baiana tem" (What is it that Bahian Woman Has?) in the 1938 film "Banana da terra" (Banana of the Land), dressed in an overly stylized costume in the style of a women's folk costume from the federal state of Bahia, representing a sort of stereotype of a woman from Northeast Brazil. At the same time, the US, wary of potential alliances with Nazi Germany, launched its Good Neighbor Policy towards Latin American countries (see Hess 2013). An important part of the cultural aspect of the new policy was also the involvement of Latin American performers in Hollywood and Broadway productions, which is where Miranda — although a native of Portugal—found her opportunity. Like the Brazilian elites, who ensured that samba would have only a decorative and non-threatening "African nature" by denying access to radio studios and licensing Carnival groups, US film studios also tailored Carmen Miranda's persona to their needs, in accordance with the imperialist spirit of US foreign policy. Her roles generally revolved around the stereotyped character of an exotic beauty, and the scripts portrayed harmonious relationships between the first and third worlds through situational comedy. The stereotypical bahiana character, developed by Miranda already in Brazil, was further caricatured by costume designers into a "typical" Brazilian woman and later a Latin American woman, along with the iconic tropical fruit hat that Miranda is still known for today (Roberts 1993; McCann 2004: 129-159).

Carmen Miranda's success story is intriguing precisely because of the multifaceted stereotypical identities she established and portrayed through her work. At the beginning of her career, she represented the exoticism of Northeast Brazil to the metropolitan residents 
of Rio. During her time in Hollywood, she first played the character of a Brazilian woman and later on simply the character of a Latin American women, along with a conglomerate of stereotypes that affirmed the orientalist picture of the third world to the US audience, allowing them easy fun in a safe environment. The emergence of Brazilian cultural nationalism described here did not occur spontaneously, but arose as a result of the personal motivations of particular elites and through interpretations of folk and popular culture. It is reflected in several spheres, be it the nationalization of samba, the mythization of interracial relations, or the establishment of a typical form of Brazilian Carnival. Simultaneously, the processes of orientalization of Brazil were taking place in the parallel centers of power of politically more influential countries, which reflected, for instance, in the banning of the "scandalous" lundu commanded by the Portuguese ruler, or in a more modern recycling of the old idea of the noble savage that Hollywood projected through Carmen Miranda's film career. It could be said that a community perceives and limits itself — and invents traditions - to the same extent as the society that assigns the identity of the Other to the first community, reducing its members' culture to ornaments or even caricaturing it to such an extent as to control and transform it in order to subsume it into its own discourse. In the second part of this article, I also highlight as a central theme the process of imagining a culture and boundaries of a community, with history repeating itself in similar ways with different protagonists. Just as Brazil sought to find a position in the world, its regions (today confined to federal states) sought to position themselves within Brazil.

\section{IMAGINING THE NORTHEAST}

Charles Wagley, an American anthropologist from Columbia University and one of the pioneers of Brazilian anthropology in the first half of the twentieth century, explicitly emphasized that Brazil had a unified national culture and divided it into six regions, interpreting them as the representatives of various shades along the palette of cultural "homogeneity." The Amazon Valley was thus wooded and tropical, with extremely strong indigenous cultural influences. He designated Sertão, located in the hinterland of Northeast Brazil, as a region of shrubby forests and cacti, characterized by recurrent drought that causes thousands to die or move to other areas of the country, with agriculture only possible in some oases. A sertanejo, a resident of the region, wearing a leather garment that protected him from desert thorns, radiated Iberian and indigenous cultural elements and was strongly affected by the wild and inhospitable environment. Of course, Wagley did not neglect to mention the religious fanaticism that was very "typical" of the region, and the prevalence of gangs of outlaws and bandits. The coastal part of Northeast Brazil, on the other hand, was characterized by fertile land. The Portuguese, who made a fortune through lucrative agriculture, made sure that a large number of slaves from Africa were settled here, which was reflected in the largest presence of African cultural elements in all 
of Brazil. It is interesting how Wagley changed his terminology as he began to describe the southern parts of the country. Areas that were previously described in the north as predominantly natural (e.g., the Amazonian rainforest, infertile desert, and fertile coastline) suddenly become clusters of federal states in the south. Thus, the extreme south of Brazil consisted of Paraná, Santa Catarina, and Rio Grande do Sul, which had a temperate climate and shared, together with Uruguay and Argentina, a gaúcho culture, a culture of South American cowboys who mostly eat meat, ride horses, and drink mate tea. Wagley characterized the states of São Paulo, Minas Gerais, Rio de Janeiro, and Espirito Santo as the industrial part of Brazil "from which modern Western culture diffuses to the rest of the country" (Wagley 1948: 460) and where industrialization smoothed the cultural differences between the federal states. This last region comprised the federal states of Goiás and Mato Grosso in the west of the country. In the 1940s, according to Wagley, this area represented the border of "civilized Brazil" (op. cit.: 458-460).

Although the regions at first glance appear to be determined by natural factors, human influence is certainly a factor in this sort of delimitation of the Earth's surface, which, through the collective memory of the imaginary past, constructs identities designed to separate one part of the national territory from another. Exposing cultural differences in the process of creating a regional identity thus goes hand in hand with the creation of the Self as a norm through which we stereotypically judge the characteristics of the culture of Others (Greenfield 2009: 395-396). Durval Muniz de Albuquerque, Jr. highlights Ceará, Rio Grande do Norte, Paraiba, Pernambuco, Alagoas, and Sergipe as the federal states that make up the region of Northeast Brazil (Albuquerque and Hallewell 2004: 48), but most authors also include the federal state of Bahia in the context of regional music (see Crook 2009). It was precisely Pernambuco and Bahia that were the political center of Brazil in colonial times, together with the city of Salvador in Bahia, which was the capital of the colony until 1752. With the abandonment of extensive cultivation of monocultures such as sugar cane and tobacco, and the subsequent industrialization, the center of power began to move south at the end of the eighteenth century, especially to major industrial cities such as Rio de Janeiro and São Paulo. The Northeast's dependence on agriculture was reflected in a discourse that began to distinguish between the modern south and the traditional north (McCann 2004: 102). Northeast Brazil-later Nordeste, from around 1920_-began to replace the role of the north as a region. Its borders are not visible in geographical features; nor is it geographically uniform. As Albuquerque writes, "The Northeast is a geographical division created in history and given reality by a tradition of thought, a way of looking at things and of writing about them" (Albuquerque and Hallewell 2004: 42-43). In the context of the emergence of this imagined regional coherency, he introduces the term "northeasternizing," which signifies the emergence of this cultural-geographical space's regional identity. The Northeast supposedly emerged as the local political elite and intellectuals' response to the national cultural discourse that threatened to merge the region with the whole of Brazil. The region was therefore conceived as a defense against the nation (op. cit.: 43-44). At the same time, it could also be said that 
in the context of Brazil, the Nordeste is seen as a sort of Orient, which is wild and different and at the same time interesting and culturally rich. In this context, it thus plays a similar role to that of the Balkans in terms of Western European self-awareness (Jezernik 2004).

The Northeast is inextricably connected with drought. Even the term Nordeste first appeared in the records in 1919, as a description of the area of activity of the Federal Inspectorate of Works Against Droughts. Ever since the Great Drought of 1877, a discourse has emerged that locates the region spatially and associates it with specific perceptions. Many residents of the southern part of the country associated the notions of the north primarily with the photographs of the consequences of drought in newspapers and fundraisers to help the victims (Albuquerque and Hallewell 2004: 44-45). Through their coverage of natural disasters and political struggles, the media significantly contributed to creating a stigma that justified the slower development of the region from the late nineteenth century. Stories of drought, banditry, clashes between family clans, and messianic superstition, along with relative underdevelopment, contributed to the stereotypical identity of the Northeast, which the residents themselves see primarily as a lack of respect from the south of the country (Greenfield 2009: 393). The lack of rainfall triggered mass migration to the south in the twentieth century, mainly to major industrial cities, thereby causing one of the country's major migratory flows in the mid-twentieth century. Drought and economic instability in the Northeast greatly impeded the livelihoods of smaller farms, causing the urban population to double between 1920 and 1950 (McCann 2004: 97).

The perceptions of Northeast Brazil thus constitute a sort of mythological microcosm based on the heroic opposition of the common man to natural and social injustices (Greenfield 2009: 396-397). Barbara Celarent points out that there is no other work that so clearly depicts the contrasts between tradition and modernity as Os Sertóes (Rebellion in the Backlands) by Euclides da Cunha, published in 1902. In the 1890s a movement led by Antônio Conselheiro appeared in Canudos, Bahia. It ultimately attracted about 25,000 followers. The newly formed republic tried to suppress the movement from 1896, and the Brazilian army put an end to it one year later with the massacre of almost all Canudos residents. As Celarent explains, Cunha, otherwise a war reporter in times of conflict, wrote this work under the influence of the working paradigm of positivism and racial studies, highlighting in the story the struggle between barbarism, which looks back to the past, and civilization, which ultimately uses the same barbaric methods. In the author's description of cattlemen, she particularly highlights the difference in discourse between the north and south of Brazil. She thus exposes the southern gaúcho as disciplined and full of energy compared to the passive and chaotic sertanejo of the Northeast. Although Canudos residents are portrayed as unusual and "Other" in the work, in the end it is the Brazilian army that turns to chaos and madness with the final massacre (Celarent 2012).

Gerard Greenfield (2009: 394) highlights three historical figures that are regional heroes who, in the eyes of the more developed south, further reinforce the stereotype of the area's backwardness. Lampião, the Bandit King, symbolizes the region as wild and 
dangerous. The wonder-working priest, Padre Cícero Romão Batista, is pointed to as a symbol of the response to political corruption in the region and folk fanaticism, whereas Luiz Gonzaga, the King of Baiáo, whom I will address in the next section, represents the peasantry, naivety, and poverty. Virgulino Ferreira da Silva, who was born in Pernambuco in 1897, is better known as the cangaçeiro Lampiâo. Due to an inter-family feud in which he lost his father under police fire in 1921, he became involved in cangaço, a Brazilian type of social banditry marked by the struggle against the privileged and helping the poor (see Chandler 2000). His companion was Maria Bonita (Beautiful Maria), about whom they still sing in the song "Mulher Rendeira" (The Lace Maker), which the cangaçeiros supposedly sang during their attack. Lampião was betrayed after almost twenty years of banditry and shot in an ambush in Sergipe together with Maria Bonita and part of his gang, and their heads were then on display at a museum in Bahia for thirty years (Greenfield 2009: 397). Because the cangaçeiros occasionally helped the poor, they acquired the status of folk heroes. Their characteristic attire, consisting of a hat with the brim upturned and embellished with stars, weapons, and a garment made of coarse leather, later became a symbol of banditry romance. During the time of the Old Republic, when power was divided among local influential people, circumstances were much more favorable toward this boom in banditry than after Vargas' takeover of the government, when centralization politics also ensured the presence of the army throughout the country (McCann 2004: 112). Immediately after the coup in the 1930s, Vargas decided to minimize local power centers and centralize power in the capital, Rio de Janeiro. He focused his attention on the northeast of the country, where he wanted to politically disable the landowning clans that had ruled the region rather independently until then. All-Brazilian patriotism became an important cultural political concept that sought to create a common, national culture. This was also achieved by broadcasting regional music deemed as more "Brazilian" on the radio throughout the country (op. cit.: 100-101).

\section{MUSIC AND REGIONALISM}

Bryan McCann shows the duality of the Northeast's cultural identity within popular music in Brazil through the personal stories of two important creators that are still ubiquitous today through their works and influence on the development of music. Dorival Caymmi and Luiz Gonzaga project a picture of two parallel regional identities of the Northeast, which Charles Wagley also hinted at in his descriptions of the Brazilian regions. Despite the differences in racial identity and different opportunities allowed by their social class, both musicians became, so to speak, the embodiments of the cultural stereotype they represented, while at the same time their music blurred the differences between folk and authorial, collective and individual, non-profit and commercial, and rural and urban; in the capital of the country, together they represented the identity of the Northeast. Caymmi 
thus manifested in his music and public image as a Baiano, a resident of the federal state of Bahia or the capital city of Salvador, whereas Gonzaga assumed the Nordestino identity, symbolically representing a native of the arid Sertáo region (McCann 2004: 97-100).

Dorival Caymmi grew up in Salvador, the capital of the federal state of Bahia, in a middle-class family that encouraged him to study, but he loved to engage in music. In search of a new form of expression, he began writing songs about the life of the fishermen he observed in the nearby village of Itapoã. His study of law brought him to Rio by ship in 1938, where, after a few initial slips, he managed to win over radio listeners with his cançôes praeiras, songs from the beach, practically overnight, a repertoire to which he later added samba songs on the topic of living in his hometown. One such is "O que é que a Bahiana tem?" (What does the woman from Bahia have?), which praises the exotic beauty of Bahia women and was also sung by Carmen Miranda. Caymmi not only included elements of local folklore, such as the region-specific words and cuisine, in his songs, but also cultivated a visual image that portrayed a typical Bahian to Rio residents. In his publicity photos, he was either playing a guitar in a hammock or dressed in the clothes of a fisherman from Itapoã. Many of his song lyrics paint pictures of exotic Bahian women and noble fishermen. Through his work he also somewhat embodied Gilberto Freyre's ideas of harmonious mestization. At the same time, as a mulatto, he was light-skinned enough to have access to the infrastructure of the music industry, which was beyond reach for some of the more dark-skinned local samba performers. Thus, he was Baiano enough to be able to perform as an urban bearer of local folklore, but not so much as to hinder him from accessing radio studios (McCann 2004: 105-111). Luiz Gonzaga, on the other hand, was born in 1912 on the outskirts of the town of Exu in the federal state of Pernambuco, and his eleven-member family lived in an environment of poverty, without plumbing, electricity, or accessible formal education. Gonzaga's father was a well-known folk musician that played sanfona, an eight-bass homemade accordion. He and his son, who knew most of his father's repertoire by the age of eight, regularly played at local dances. At seventeen, Gonzaga joined the army, and his battalion's task was to fight the cangaçeiro bandits mentioned above. He later switched from sanfona to piano accordion. At that time he was listening to radio music broadcast by the stations in Rio de Janeiro (thus, the urban samba and choro), and he was most impressed by Dorival Caymmi and his ability to combine Bahian musical elements with contemporary music production in the capital. Due to his work in the army, Gonzaga moved around the country and eventually landed in Rio, where he began to play music at local popular music venues, thus ending his military career. At one of his performances at the Mangue bar, a group of students from the northeast federal state of Ceará, who recognized Gonzaga's accent despite his effort to conceal it, requested that he play some folk tunes. Gonzaga, who had not played that sort of music for nearly a decade, was unable to grant them their wish, so he spent the whole next week relearning the songs he had played with his father as a child. The next time he repeated the event, he gave them an accordion concert, which also attracted people from the surrounding streets. Later, with 
a similar repertoire, he won a talent competition, which paved the way to radio stations, especially those that played "country" music. Although he was establishing himself as an instrumentalist by playing his music on the radio, the editors were not too impressed with his "peasant" accent. He also made a living playing more southern, "folk" music, such as the sertanejo and caipira from the surrounding area of São Paulo (see Reily 1992). When he met Humberto Teixeira, a lawyer from the federal state of Ceará, in 1945, they created a genre that represents one of the pillars of Brazilian music to this day. One of the first hits, a tale of drought, love, and migrations called "Asa Branca" (White Wing) was created using a folk tune that remained in Gonzaga's memory from his childhood as a basis, while Teixeira added the lyrics (which were also based on Gonzaga's memory). The performer further accompanies all of this with an exaggerated dialect and local sense of melancholy, which soon made the song the unofficial anthem of the region of Sertão. The second song, "Baião," was even more successful. The whole rhythmic structure is based on the folk way of playing the viola caipira (country guitar; see Waddey 1980), specifically the rhythm that the violeiro plays before starting a song. Consequently, "Baiáo" became one of the most important rhythms of the musical genre known today as forró and secured Luiz Gonzaga a permanent place among the most popular musicians (McCann 2004: 111-117).

Both Caymmi and Gonzaga succeeded due to the commercialization of their perceived regional cultural "authenticity," which was established through the image that residents of the capital had about the region. A large part of the image cultivated for the public was the performers' physical appearance. Along with sambistas wearing sailor shirts, southern gaúchos with their cowboy attire, and Baianos with straw hats, Luiz Gonzaga likewise soon abandoned his tuxedos and linen suits and instead put on a large embellished leather hat, thus symbolically becoming a Nordeste stereotype: an outlaw called Lampiáo. In parallel, Gonzaga even changed his racial identity throughout his career as a sort of contemporary Macunaíma. He initially presented himself as a mulatto and cosmopolitan carioca (resident of Rio de Janeiro), but later on, with his transformation, became a sertanejo, practically a caboclo or Nordestino (McCann 2004: 111-117). Caymmi's story, and to a greater extent Gonzaga's, in some ways represent similar processes to those of Carmen Miranda's career, but at the local level. One could even say that Miranda continued Caymmi's work globally. The commercial success of all three performers was conditioned by ideologically accommodating the social elites, who in this case acted as gatekeepers. Thus, Caymmi, a middleclass mulatto, had greater access to music studios than Gonzaga, a poor man from the arid Northeast who only developed a flourishing career after collaborating with a lawyer who wrote lyrics. At the same time, the fair-skinned Carmen Miranda was likely to enjoy better opportunities for an international career. As a Baiano, Dorival Caymmi was much more successful than Gonzaga in blending with the myth of racial democracy and the boom of the urban samba that simultaneously took place in Rio. Although interest in the music of the Northeast in the capital was not new (see also Crook 2009: 149-174), Gonzaga's case is a special example of the stylization of regional stereotypes. 


\section{CONCLUSION}

Ruben George Oliven (1984: 104) refers to Menezes Bastos when he mentions the processes of the cultural domination of elites, who first cleanse the unwanted content from the folk and popular culture and then offer it back for consumption in a changed form. This process is ubiquitous throughout the history of the development of cultural nationalism, as evidenced by the examples highlighted here. At the end of the colonial period, the upper classes' guilt was assuaged by De Alencar's work, which was continued by Freyre after the abolition of slavery, through the relativization of relations between Africans and Europeans. Classically educated Heitor Villa-Lobos added decorative folk motifs to his artistic works, turning them into charming ornaments by purifying the context. Getúlio Vargas contributed the lion's share with his cultural policy, which included samba in the pantheon of "legitimate" Brazilian musical genres but only under certain conditions. The radio programmers in Rio de Janeiro provided access to the studios only to "desirable," especially light-skinned, musicians, and by adding arrangements, placed samba in a completely decorative context. At the same time, samba schools became recreational societies, securing their place at Carnival only by following government instructions. Carmen Miranda's success can also be attributed to her playing by the rules of the game. In the context of this paper, her role is particularly interesting because, despite her Portuguese origin, she managed to build an international career by imitating a woman from Northeast Brazil and, ultimately, in a caricatured way representing all of Latin America. Dorival Caymmi, the author of Miranda's first hit, and Luiz Gonzaga adapted their regional musical expression to the taste of radio editors and listeners from the capital. Although they both built successful careers throughout the entire country and are still popular among the people of their native regions today, it was precisely meeting the expectations of the Cariocas, the inhabitants of Rio, that enabled them this success. Thus, drought and poverty turned into romance, social problems associated with emigration to nostalgia, an Afro-Brazilian student into a dreamy fisherman, a dangerous Lampiáo bandit into a smiling accordionist, and thus the imagined culture of the uncultivated Northeast became more easily manageable to the upper classes.

Soon after the establishment of Brazilian independence from the Portuguese crown, the process of imagining a common identity was thus established. Social elites first addressed the question of racial inhomogeneity of the population with the help of "whitening" and later by establishing a myth of racial democracy that tried to sweep the injustices committed during the time of slavery under the rug. Based on the transformations of Afro-Brazilian musical practices and with the help of the mass media, throughout the twentieth century an all-Brazilian musical culture was created, which stemmed from the urban samba from Rio de Janeiro and was spread throughout the country with the help of radio waves. Just as Brazil represented the exotic Orient in the eyes of the US, the Nordeste played a similar role within the country itself. The musicians that travelled to the capital in the hope of achieving commercial success adapted their folk culture accordingly, contributing to the emergence of new musical expressions within the treasury of Brazilian music. 


\section{REFERENCES}

Albuquerque Jr., Durval Muniz de, and Laurence Hallewell. 2004. Weaving Tradition: The Invention of the Brazilian Northeast. Latin American Perspectives 31 (2): 42-61.

Anderson, Benedict. 2006 (1983). Imagined Communities: Reflections on the Origin and Spread of Nationalism. London, New York: Verso.

Bollig, Ben. 2002. White Rapper / Black Beats: Discovering a Race Problem in the Music of Gabriel o Pensador. Latin American Music Review / Revista de Música Latinoamericana 23 (2): 159-178.

Borges, Dain. 1995. The Recognition of Afro-Brazilian Symbols and Ideas, 1890-1940. Luso-Brazilian Review 32 (2): 59-78.

Celarent, Barbara. 2012. Rebellion in the Backlands by Euclides da Cunha. American Journal of Sociology 118 (2): 536-542.

Chandler, Billy Jaynes. 2000. Bandit King: Lampião of Brazil. College Station: Texas A\&M University Press.

Chasteen, John Charles. 1996. The Prehistory of Samba: Carnival Dancing in Rio de Janeiro, 1840-1917. Journal of Latin American Studies 28 (1): 29-47.

Crook, Larry. 2009. Focus: Music of Northeast Brazil. New York \& Oxon: Routledge.

Dunn, Christopher. 2001. Brutality Garden: Tropicália and the Emergence of a Brazilian Counterculture. Chapel Hill: University of North Carolina Press.

Enciclopédia Itaú Cultural de Arte e Cultura Brasileiras. 2017. Pelo Telefone (1916). http://enciclopedia. itaucultural.org.br/obra7091/pelo-telefone-1916.

Fry, Peter. 2000. Politics, Nationality, and the Meanings of "Race" in Brazil. Daedalus 129 (2): 83-118.

Fryer, Peter. 2000. Rhythms of Resistance: African Musical Heritage in Brazil. Michigan: Pluto Press.

Garcia, Thomas G. 1997. The “Choro," the Guitar and Villa-Lobos. Luso-Brazilian Review 34 (1): 57-66.

Greenfield, Gerald. 2009. Lampião, Luiz and Padim Ciço: Three Icons of the Brazilian Northeast. Memory Studies 2 (3): 393-410.

Hess, Carol A. 2013. Representing the Good Neighbor: Music, Difference, and the Pan American Dream. Oxford: Oxford University Press.

Hobsbawm, Eric. 2000 (1983). Introduction: Inventing Traditions. In: Eric Hobsbawm and Terence Ranger (eds.), The Invention of Tradition. Cambridge: Cambridge University Press.

Jezernik, Božidar. 2004. Wild Europe: The Balkans in the Gaze of Western Travellers. London: Bosnian Institute.

Marx, Anthony W. 1996. Race-Making and the Nation-State. World Politics 48 (2): 180-208.

McCann, Bryan. 2004. Hello, Hello Brazil: Popular Music in the Making of Modern Brazil. Durham: Duke University Press.

Menezes Bastos, Rafael José de. 1999. The "Origin of Samba" as the Invention of Brazil (Why Do Songs Have Music?). British Journal of Ethnomusicology 8: 67-96.

Moric, Anja. 2020. Gottscheer Folk Song - From a Means of Fostering National Differentiation to a Memory Keeper in the Diaspora. Traditiones 49 (2): 141-166. DOI: https.//doi.org/Traditio2020490208.

Murphy, John P. 2006. Music in Brazil. New York and Oxford: Oxford University Press.

Oliven, Ruben George. 1984. The Production and Consumption of Culture in Brazil. Latin American Perspectives 11 (1): 103-115. 
Reily, Suzel Ana. 1992. Música Sertaneja and Migrant Identity: The Stylistic Development of a Brazilian Genre. Popular Music 11 (3): 337-358.

Reily, Suzel Ana. 2000. Introduction: Brazilian Musics, Brazilian Identities. British Journal of Ethnomusicology $9(1): 1-10$.

Roberts, Shari. 1993. “The Lady in the Tutti-Frutti Hat”: Carmen Miranda, a Spectacle of Ethnicity. Cinema Journal 32 (3): 3-23.

Santos, Sales Augusto dos. 2002. Historical Roots of the "Whitening” of Brazil. Latin American Perspectives 29 (1): 61-82.

Shaw, Lisa. 2002. Samba and Brasilidade: Notions of National Identity in the Lyrics of Noel Rosa (1910-1937). Lusotopie 2: 81-96.

Sheriff, Robin E. 1999. The Theft of Carnaval: National Spectacle and Racial Politics in Rio de Janeiro. Cultural Anthropology 14 (1):3-28.

Vassberg, David E. 1976. African Influences on the Music of Brazil. Luso-Brazilian Review 13 (1): 35-54.

Veloso, Caetano. 2002. Tropical Truth: A Story of Music \& Revolution in Brazil. New York: Da Capo Press.

Vianna, Hermano. 1999. The Mystery of Samba: Popular Music and National Identity in Brazil. Chapel Hill: The University of North Carolina Press.

Waddey, Ralph C. 1980. "Viola de Samba" and "Samba de Viola” in the Recôncavo of Bahia (Brazil). Latin American Music Review / Revista de Música Latinoamericana 1 (2): 196-212.

Wagley, Charles. 1948. Regionalism and Cultural Unity in Brazil. Social Force 26 (4): 457-464.

Williamson, Edwin. 1992. The Penguin History of Latin America. London: Penguin Books.

\section{BRAZILSKA GLASBA MED NACIONALNIM IN REGIONALNIM}

Stiki med Južnoameričani, Evropejci in Afričani so že v obdobju kolonizacije območja, ki ga danes poznano pod imenom Brazilija, vplivali na razvoj novih kulturnih izrazov. Po vzpostavitvi brazilske neodvisnosti od portugalske krone se je v Braziliji začel proces zamišljanja skupne identitete. Ideologi družbenih elit so se sprva ukvarjali predvsem z vprašanjem rasne nehomogenosti prebivalstva, ki so ga najprej reševali s politiko 'beljenja', pozneje pa š̌irjenjem mita o rasni demokraciji, ki naj bi odpravil krivice, storjene v času sužnjelastnistva. Vsebrazilska glasbena kultura je zasnovana na predelavah afro-brazilskih glasbenih praks; urbano sambo iz Ria de Janeira so množični mediji v 20. stoletju razsivirili po vsej državi. Brazilija je s podobo plesalke sambe Carmen Miranda in promocijo karnevala v Riu de Janeiro idejo o "homogeni" brazilski kulturi uspela ponesti prek svojih meja. Podobni procesi so se odvijali tudi v kontekstu zamišljanja regij znotraj države. Včlanku je opisan primer severovzhodnega dela Brazilije, tj. območja Nordeste. Podobno kakor so npr. ZDA na Brazilijo gledale kot na eksotični Orient, so $v$ Braziliji dojemali svoj Nordeste. Tudi v tem primeru so na razvoj glasbenih oblik močno vplivali osebni interesi posameznikov, npr. družbene elite, ki so nadzorovale radio in druge medije, ali pa različne motivacije ustvarjalcev. Glasbeniki, ki so vželji po komercialnem uspehu 
potovali v glavno mesto, so ljudsko kulturo ustrezno prilagodili in s tem prispevali k nastanku novih glasbenih izrazov v zakladnici brazilske glasbe. Članeks pomočjo teoretičnih, zgodovinskih in etnografskih virov drugih avtorjev, specificnimi primeri, anekdotami in historičnimi utrinki ilustrira procese, ki so pripeljali do oblikovanja nacionalnih in regionalnih glasbenih izrazov v Braziliji.

Andrej Tomazin, Senior Expert Associate ZRC SAZU, Institute of Ethnomusicology

Novi trg 2, SI - 1000 Ljubljana, Slovenia, andrej.tomazin@zrc-sazu.si 